\title{
The process of globalization, and its impact on the physical form of Islamic cities, with an emphasis on Iran
}

\author{
Elham AMINI*1 ${ }^{1}$, Niloofar SEDGHI ${ }^{2}$, Mohammad Saber EsLAMLOU $^{3}$, Adel GorJINIA ${ }^{4}$, Tara GHASEMI ${ }^{5}$ \\ 1. Assistant Professor Islamic Azad University, Pardis Branch, Tehran, Iran \\ 2 - Ph.D Student in Urban Planning Azad University, Tehran Markaz Branch, Tehran, Iran \\ ${ }^{3}$ - Ph.D Student in Urban Planning Azad University, Qazvin Branch, Qazvin, Iran \\ 4- Ph.D Student in Urban Planning Azad University, Tehran Shomal Branch, Tehran, Iran \\ 5- Master Student of Urban Design, Islamic Azad University, Tehran Markaz Branch, Department \\ of Architecture \& Urbanism, Tehran, Iran \\ *Email: Dr.elham_amini@yahoo.com
}

\begin{abstract}
Globalization is seen beyond avoidance Due to the expansion and strengthening of mass communication and media are and quickly in all dimensions and aspects of human life, especially culture, society, economy and politics has penetrated And all aspects of human life is affected. Understandings of the phenomenon and the challenges and strategies for dealing with the most important responsibilities of scientists and experts from different countries are at present. The present study was to understand the importance and challenges of globalization and the threats against the Islamic Republic of Iran to analyze this phenomenon and Develop and submit to the demands of the 21st century, the country's main strategies in dealing with globalization of culture, society, economy and politics is discussed. The results show that the strategies for dealing with globalization, It can be said that the implementation of strategies and opportunities that it creates For the protection of cultural and social identity important part of our identity is a need to strengthen and enhance the level of cultural, social and economic Gmarym efforts Protecting and preserving the rich culture and customs of the whole Islamic world is ready to face the new approaches to the interests of our country.
\end{abstract}

Keywords: globalization- global globalization of culture, society and Economics Globalization Challenges and Strategies.

\section{1- Introduction}

Much has been said today about an important event in the era of globalization and urbanization and its evolution over the past three decades, has reached a high level. In other words, during the past thirty years, the city at the global level, more than double matured. According to UN projections over the next thirty years this phenomenon will be repeated in urban areas in developing countries. So that the urban population in these regions of the world, of the 9.1 billion people in 2000 to 4 billion threshold in 2030. While the rest of the world, the advanced industrial countries, at the same time the figure of 900 million to one billion (Chaste land \& Chesnais, 1997). If you are currently an average of 38 percent of Africa's population live in urban areas, according to UN forecasts and studies by 2030 this figure will increase to 55 percent. But this is especially important in Asia. Because of population growth on the continent's socio-economic and political determinants of regional and global developments exist, each of them dedicated to seasonal demands. The continent due to its population size, in 2030, a considerable number of the population will be urban. Although the current rate of urbanization in large parts of the continent, according to US estimates of population studies is low, But the United Nations has reported that between 2000 and 2030, India alone, 345 million people, Pakistan and Bangladesh are close to 100 million new citizens will be over 50 million. Notably, the impact of "mega-cities" in this evolving and we must say that in all developing countries from a total of 19 cities with more than 10 million people globally 15 cities included in this total, and by 2015 , the 23 cities with demographic characteristics mentioned, the number of 19 cities will be in the same group, respectively, Asia 13, Latin America and Africa 2 it will be four. In addition, by 2015 large set of developing

\footnotetext{
1 - Corresponding Author
} 
countries, 400 cities will be counted, which will have a population of over a million people. But Latin America's situation is different than the other two continents. In this area between 2000 and 2030, the proportion of urbanization will increase from 75 percent to 83 percent (United Nations, 2001). The changes resulting from this event has great impact on the body of Islamic cities, The purpose of this study is to investigate the process of globalization and its impact on the body is that of Djenné different Muslim cities were evaluated.

\section{Research Methodology}

In this paper, the process of globalization and its impact on the body of Islamic cities, and its impact on the architecture, and the body of Islamic cities, Using comparative and analytical study based the documentary and library were studied. It also compares contemporary architecture in the world's most important architectural difference between these cities during the era of globalization, its impact on the body of Islamic cities were evaluated.

\section{The Research Objectives}

The overall objective of this study was to investigate the effects of globalization and its impact on the body of Islamic cities, and answer the questions that?

1. The greatest challenges facing the world in the body of Islamic in what will be?

2. Is globalization has had an impact on the architecture and shape of the Urban Iran?

This study seeks to understand the facts that embody a result of globalization in recent years and especially in Iran happened in Islamic cities. Which is to be discussed within the framework of a comparative study.

\section{Concepts and Theoretical Research \\ 4.1 Concepts and Definitions of Globalization}

The term globalization of the Western countries, especially the United States of America has been proposed And in the semantic sense can be regarded as an expression of the wishes of its leaders. But globalization also can be considered as a phenomenon affecting and affected in a social process, a variety of effects and consequences. The concept of globalization from the mid 1980s onwards was more common. Expand it to a particular concept of sociology at the University of Pittsburgh's most indebted Rvlandrabrtsvn World as a single location at a more abstract level of the international system, governments are actively engaged in the following activities:

Division of power at the international level or at the continental level to establish collective security, value creation and global norms, for example in the field of social and political rights, The use of nuclear power and the principles relating to the use of force, adjusting the distribution of the international classification of countries through the reallocation of economic resources and coordinate the exchanges between countries in the fields of trade, migration, Cultural functions, etc., in which the three major gap in the international system to prevent systematic world are facing: Religious divide, divide legal - diplomatic, industrial divide.

Mac depends on the general concept of globalization such as the: Increase the number of links and interactions with the government (and thus beyond the communities) to spread fuel, the new system will make a world. Globalization refers to the process through which events, decisions and activities in one part of the world can Important implications for individuals and communities in very remote parts of the globe is on. (Vdad.ach Imran, 1370). And Thomas Friedman believes that the issue of the World "Globalization is not just an economic process and on the other hand also is not a passing wave. But like all previous international system directly or indirectly, domestic politics, foreign economic and shapes almost all countries. "(Thomas Friedman, 1380, p. 15). Another American scholar James Roznov, Neamt about various topics such as globalization and the relationship between states: "The globalization of communication between different levels of integration of economic, political, cultural and ideological re-production planning, cross-border communication industry, expanding investment markets, standards and consumer countries as a result of conflict and struggle of indigenous and immigrant groups covers "

Globalization and its impact on the David Harvey argues that: "Globalization has entered a new stage of compression of time and space, which is confusing and detrimental impact on the process of political, economic, social and cultural life and the balance of class power". But the complexity of globalization albero Martin says: Globalization, but distinct set of complex processes in the areas of politics, economy, culture 
and thought that everything will change, but emerged from the history. First, this is a process, not a project, the latter being universal. Third, it is huge and covers every aspect of your life "(Said, 1385, p. 80). Globalization is defined as follows:

"The increasing compression of time and space due to the rising world population and relatively more or less conscious of the international community will be merged. In other words, globalization is a process that involves the individual and society in the world encapsulation bonded "(Tamilson, 1381, p. 20).

\section{2 architecture in the Islamic world}

Islamic art is almost a dynasty, "Umayyads" in the year $41 \mathrm{AD}$. AH and transfer the Umayyad Caliphate from Medina to Damascus, came into being. With this transfer, Islamic art combines the art of neighboring countries, especially Iran. Islamic conquest in the seventh century led early Islamic architects to borrow and adopt many of the traditions and practices of the Persian Empire fell. Islamic architecture of Persian architecture and can therefore borrow some from what is called the spread and further evolution of Persian architecture. Iran and Central Asia, TAHERIAN, Samanids, Ghaznavids, and Ghori attempt to power in the tenth century, and art was a vital element of the competition. Big cities, have been built, such as Nishapur and Ghazni (Afghanistan), and the construction of the Great Mosque of Isfahan (which would continue, in fits and starts, over several centuries) was initiated. Funerary architecture are also cultivated. The advent of architecture in the Islamic world is one of the biggest effects on the body of material is considered an artistic truth. Historically, Henry's first architecture that could be made compatible with Islamic concepts, be welcomed by the Muslims. Islamic architecture as one of the most successful architectural practices in the history of architecture is world recognition. In a comprehensive look at the rich and dynamic continuum in recognition of Islamic monuments that made them all together in the same mold as Islamic architecture are (Mohamadinejad, 1383).

\subsection{Foundations of Islamic city}

Characteristics of buildings and cities, in a society, the cultural elements of unyielding and gradually, himself, in the context of the cultural penetration. The jurisprudence, legislation in the field of construction organize and sort them. The provisions of the original Islamic concepts such as private property rights and freedom have taken possession of it and make changes. This freedom, freedom is not absolute limit that the hadith of the Prophet "without loss and without Dirar" stems. In this framework limits the appearance of Islam in the buildings which should be the appearance, While observing a lien for the owner, it was not the harassment of others. Being on the main street in the city markets can be seen that the market should not create a nuisance for residential neighborhoods. The provisions of the loss and inconvenience will be summarized in three things: Smoke, odor and noise. And this has led to industrial workshops outside the city limits and annoying odor or smoke in places where wind from the workshops through the city not transfer. (Brotherhood, diamond oven, philosophy, 1389: 81 and 80).

Table 1: Foundations of Islamic city

\begin{tabular}{|l|l|}
\hline $\begin{array}{l}\text { Characteristics } \\
\text { of Islamic city }\end{array}$ & Explanation \\
\hline Physical space & $\begin{array}{l}\text { Space is not only a mere form of human flesh from the Islamic perspective Composite } \\
\text { great spirit he has created. }\end{array}$ \\
\hline The physical space & $\begin{array}{l}\text { The body of precise orientation, accurate calculation and mapping of water and soil as } \\
\text { well as physical confrontation, the most important indicator vast spaces Islamic cities. }\end{array}$ \\
\hline $\begin{array}{l}\text { Mosque and the } \\
\text { Mosque }\end{array}$ & Driven by city \\
\hline schools & The highest virtue Muslims \\
\hline Stability & Imam Sadiq says: Everyone who implant materials, the building will not reward him. \\
\hline Garden & Nikko God \\
\hline Beauty & Friend of God \\
\hline $\begin{array}{l}\text { Order and } \\
\text { symmetry }\end{array}$ & By creation \\
\hline Security & Security Life = public health \\
\hline
\end{tabular}

Source: (Hossein Zadeh, 82: 1389) 


\subsection{Physical form of Islamic cities}

Professor Ahmad Ashraf on the Urban Islam said: "The cities that Islamic rulers founded on two main foundations: one mosque and other markets. Mosque building as the spiritual center of the city and the area under its influence, in the appropriate place on the main Shahrh, in a large area rectangular shape, was built. The main mosque in the center of the camp sovereign state or vice it. On the other hand, sometimes around the market had Mosque (fraternities, diamond oven, philosophy, 72: 1389). The Muslim world is a mirror in your geographic features of the Islamic civilization. At the same universality of Islam was born in the city and the city expanded. In the history of Islamism in the Muslim areas of large cities grew, the central cities of Islam in every respect and is placed behind small and medium cities was also greater. What distinguishes the first mosque in the Islamic city of the "village" was. Islamic cities of the legal opinion at the beginning of a feature that distinguishes them from the village came and it was a comprehensive and pulpit.

Table 2: Urban elements in the area of Medina and Rabath

\begin{tabular}{|c|l|}
\hline Urban Elements & \multicolumn{1}{c|}{ Brief descriptions and explanations } \\
\hline Medina & A city or town \\
\hline Borough & Fortified settlements (Castle rulers) \\
\hline Rabath & Older located in the vicinity of the central city suburb Bkhz \\
\hline Tyre & Dyvarshhr (Barrow) \\
\hline Chapter & Gate City \\
\hline Tower & Fortified tower \\
\hline Lawyer & Street across the public \\
\hline Batha / beach & $\begin{array}{l}\text { Square or public place, these elements are usually created at the intersection of } \\
\text { three streets in Tunisia and called Mqs. }\end{array}$ \\
\hline Preparedness & Outdoor range to hold Eid prayers in the vicinity of Medina \\
\hline Tomb / Jbanh & General Cemetery \\
\hline Fall / Majl & Storage facilities, large public / private water source water \\
\hline Ditch & The main route of the city sewer or ditch \\
\hline The Neighbourhood & $\begin{array}{l}\text { A term that is used in Tunisia. } \\
\text { A term used in Egypt } ~\end{array}$ \\
\hline Sermon & aburbs
\end{tabular}

Reference: (Hakim, 269: 1381)

The years following World War, New York is the epitome of Modern prosperous center of trade and exchange with and wealth and transfer billions of dollars a day monitoring. Wall Street is the heart of New York and of course the modern world. Around this central core, modern comets formed the centers of civilization facilitator. Gambling and recreation centers, prostitution, games, music is easy due to the expansion of civilization is not a center but it's important to have a great city. The Las Vegas with hundreds of brothels - shopping centers, power centers, media centers and ... Of course towers as a symbol of the evil of the modern American man and has been soaring, sky have been scratched. Based on the above it is clear that both traditional and modern in the center, and are optimized to an end, Traditional cities and life are optimized for worship and submission, and modern cities, rebellion, subjectivity and seizing wealth and well-being and pleasure are optimized, Isfahan was once the garden of earth and heaven New York today Andes wealth of the modern world. 
Table 3: Central cities in different periods of urbanization

\begin{tabular}{|l|c|l|}
\hline \multicolumn{1}{|c|}{ Around } & Center & \multicolumn{1}{c|}{ Course name } \\
\hline House, Senate, urban streets, halls, theaters and ... & Agoura & Greece (400 BC to 30 BC) \\
\hline $\begin{array}{l}\text { House, Senate, urban streets, halls, theaters, } \\
\text { gladiators, baths, barracks and .. }\end{array}$ & Forum & Roman (30 BC to 500 BC) \\
\hline $\begin{array}{l}\text { Farmers houses, arable land (combined city is very } \\
\text { close to the Islamic cities) }\end{array}$ & House church & $\begin{array}{l}\text { Christian faith Ages (500 to } \\
\text { 1500 AD) }\end{array}$ \\
\hline $\begin{array}{l}\text { Churches, palaces, farms, Greek and Roman statues } \\
\text { and Back icons }\end{array}$ & $\begin{array}{c}\text { Square rally } \\
\text { (Shhrdary- market) }\end{array}$ & Renaissance (1500 to 1700 AD) \\
\hline Municipalities, markets, churches, farms & Palaces & Baroque (1650 to 1700 AD) \\
\hline $\begin{array}{l}\text { Markets, shops, church } \\
\text { Roundabout }\end{array}$ & $\begin{array}{l}\text { Enlightenment (the width of the } \\
\text { Baroque) }\end{array}$ \\
\hline Workers' homes and slums, home financiers, church \\
\hline $\begin{array}{l}\text { Tower, station, train, subway, banks, theaters, } \\
\text { cinemas, post, telegraph, hospitals, streets, car kits and } \\
\text { all the modern institutions of urbanization }\end{array}$ & $\begin{array}{c}\text { Factory } \\
\text { Tower, highways, subways, casino, bank, hospital, }\end{array}$ & $\begin{array}{l}\text { Twentieth century to World War } \\
\text { II }\end{array}$ \\
\hline
\end{tabular}

\section{Main elements of the Islamic body}

$\mathrm{TV}$ and shape the course of consideration of other aspects of urban life shows that perceptions of the analysis completes the features of the city; It also indicates other basic elements when defining the city is important. In this regard, we must inevitably focus of urban physical spaces and recognition scheme, and then based on the importance of those elements and spaces in the urban environment, Imagine the shape of a city; Since the existence of the city as the embodiment of social, economic, political and culture in the city and it is one of the physical space, with recognition of the city's physical space, the possibility of recognition forces, flows and structures of the dominating urban life is afforded a period. Accordingly, the central elements of the city in the Middle Ages, briefly explained, to be more accurate understanding of the existence of the urban phenomenon were awarded during this period.

A): The citadel, Arg as a political body, reflects the political power in city and regional, urban and spatial focal point for seating governing brokers and other affiliated and related facilities. This model, significant changes in this period reflected the economic and social relations.

B): Mosque: Another important element of the urban fabric and symbol of the religious system in which the space Astqraryaby significant pattern was followed in the vicinity of the market and organ. Scientific and cultural institutions associated with additional spaces next to it fell Mosque stay the exact same. The changes that occurred in the community during religious relations, physical spaces such as monasteries and schools were built in cities that also influenced the shape of a city (Pirnia, 1366: 221).

C): Market: original atmosphere of the urban fabric of space in harmony with the body organ and the Mosque and the main lines connecting the city was established. Market space, relations of production and trade had manifested in your body.

D): Quarter: another space of the city body that also function as organizing social space, urban, social function (maintaining social cohesion, the establishment of social control, identification of community members, ..., culture (spatial resolution groups. doctrinal distinctive, ..., administrative (security and order in the district, management of community affairs, etc. and urban (having public institutions such as baths, marketplaces, mosques, schools, ... as well. Evaluation of the main elements of Iranian cities in the Middle Ages and analyze the pattern and how to locate the main elements of urban life in the city and compare them with the pattern Fzayaby main elements of the Iranian Sasanian Persia and the early Islamic centuries, significant differences in the way Samanyaby and spatial arrangement of elements. In the Middle Ages, the political process of social change, with different perceptions of politics and statecraft was dominant, led the new urban pattern emerged in the Suburbs area and the most important part of the city's physical transformation. Discussed changes in the shape and movement of the main elements of urban life in cities was accompanied by the appearance of Rabath region, socio-economic growth of the city took place. 
Bulletin de la Société Royale des Sciences de Liège, Vol. 85, 2016, p. 1601 - 1613

Table 4: Fundamentals of Architecture and Urbanism - Islamic

\begin{tabular}{|c|c|}
\hline $\begin{array}{l}\text { Architecture } \\
\text { and urban } \\
\text { design } \\
\text { principles - } \\
\text { Islamic }\end{array}$ & Principles of sustainable architecture and urbanism \\
\hline People Heir & $\begin{array}{l}\text { - Improved quality of life and physical and spiritual well-being and social and } \\
\text { economic justice. } \\
\text { - Create the phenomenon as the most important part of the logical structure, } \\
\text { making smart urban Iranians to back Press townspeople in different sizes and } \\
\text { locations. } \\
\text { - Use proportions and materials used in body size and architecture of the city, } \\
\text { to create spaces and glorious joy, not to oppress the people and instill a sense of } \\
\text { insignificance and despise them. } \\
\text {-A common architectural fit with the surrounding tissue. }\end{array}$ \\
\hline $\begin{array}{c}\text { Avoid } \\
\text { idleness }\end{array}$ & $\begin{array}{l}\text { - The design and use of space based on the needs of multi-functional spaces } \\
\text { and flexible space to avoid wasting space, resources, materials and energy. } \\
\text { - Creating open spaces and vast fields around the downtown and } \\
\text { neighborhoods. }\end{array}$ \\
\hline Autarchy & - Future resources to meet human needs without taking the local approach. \\
\hline Introspection & $\begin{array}{l}\text { - Harmony with nature and its energy use and reduce consumption of non- } \\
\text { renewable resources. } \\
\text { - Link green spaces within the urban fabric of the city and its architectural } \\
\text { fabric of Garden City. }\end{array}$ \\
\hline Niaresh & $\begin{array}{l}\text { - Using modular in design and functional structures and sustainable and } \\
\text { recyclable materials. }\end{array}$ \\
\hline
\end{tabular}

Source: (Pirnia, 36: 1383)

Iranian town - Organization of the Islamic approximately constant, The main centers is based on the formation of public functions in itself, Ways to be drawn between the gate and urban squares, That have organized public functions and among them, the main routes into the market and will be covered. A hierarchy of roads, urban elements such as gates, the market square and other cells bind to each other. The city of Iran, has been the backbone of a clear and defined focus. That in proportion to their importance are location relative to the main axis of the city. The formation of independent community-based organizations as meeting the needs of city living with ethnic cultural communication. In general, Iranian-Islamic ancient cities with the spatial link between the state of economic, social, administrative, cultural and environmental, and sustainable integrated system have formed. Some features of these cities to achieve sustainable cities is as follows:

- Urban coherence and a unified set.

- Observe the urban hierarchy into three categories: public, semi-public and private.

- The social structure of the group and neighborhoods along religious and economic dimensions of security and social identity.

- Match the physical structure of terrain and climate and environment valuation of the elements of nature.

- Continuous formation of urban spaces among housing units enclosed spaces (courtyard) with respect to access the hierarchy of the social system and privacy.

- Physical integrity and the market environment and the community with each other and with the most important centers of economic, administrative and cultural city (Soltanzadeh, 6: 1362).

\section{Globalization and its impact on the body of Islamic cities}

Iranian-Islamic architecture with modern architecture and urbanism are significant differences in the following table are shown the characteristics of these two types of architecture: 
Table 5: the distinction between Islamic and modern urbanism

\begin{tabular}{|c|l|l|}
\hline Subject & \multicolumn{1}{|c|}{ Common } & \multicolumn{1}{c|}{ Distinctions } \\
\hline \multirow{3}{*}{$\begin{array}{c}\text { Iranian-Islamic } \\
\text { architecture }\end{array}$} & - Simplicity and the use of noble and & 1. Surface Negra \\
& - Anterstandable form. & 2 according to the weather \\
& - Pay particular attention to the & 3. Producer (architect) can not be seen \\
in the plan.
\end{tabular}

Source: (zendedel, 1392)

Generally four basic dimensions of globalization can be in the body of the Islamic and Muslim cities have been considered in this study:

- The first dimension: identity, ecological environmental

- The second dimension: the socio-cultural identity

- The third dimension: economic identity

- The fourth dimension: physical-spatial identity

\section{1 ecological environmental globalization and identity in Islamic cities}

The natural environment as a context for human activity, is a system structure. This system has the characteristics of qualitative and quantitative elements that form the structure of the environment. Each of these components jointly certain role in all these roles - creates environmental performance. The whole structure is consistent with his character backgrounds and different substrates for active humans; In other words, the type of environment and its performance in different places and at different time scales to the formation of different forms of life and different behaviors (and thus creating different perspectives) is in the process of globalization. This is a factor in every corner of the globe particular form of human life, plants and animals to govern. In fact, the formation of different types of human settlements and activities in a variety of different locations is a response to the actions of elements found in nature. In general, this approach to identity environment as a context for human activity could lead to better analysis of the various forms of life and human activity. This post has been extensively studied, Therefore, the environmental aspects of identity related to the era of globalization, the introduction of geographical location and natural, ecological environmental factors have been studied and analyzed the most important ones are:

- Topography

- Network streams and surface runoff

- Features Climate (including rainfall, temperature, humidity, wind, etc.)

- Surface water and groundwater resources

- Geological structure

- Vegetation and animal life

- Natural resources and attractions (the section in the scale of urban and suburban thoroughly investigated).

\section{6-2 globalization and socio-cultural identity in Islamic cities}

It is said that the only thing that concerns identity, man. Man has always sought a means by which to explain it. Obviously, it is not possible to explain themselves in a variety of others, because the identity of 
the person is an individual part of the sphere of social life, with its own aims. On the other hand person and growing presence in public, in addition to personal identity, the name, status and personal relationships with others will, but with common elements that is called culture, the collective identity. Science, technology, skills, ideas and experiences of others or the last value and usefulness that we win or we will be in the final analysis of the components of identity, as the line, clothes, production methods, customs and beliefs, celebrations and festivals and many other things that national component of their culture and identity elements and attributes we know, Transition and transformation in its history and in the course of trade and exchange with others we have gained. Accordingly, due to socio-cultural identity in urban society toward true identity is inevitable. So, in this collection have been considered in detail. In general the studies related to this dimension of identity in the globalization process, indicators have been extensively studied and the following dimensions:

- Demographics: The population of the impact of globalization on quantitative and qualitative characteristics include the number of time periods, age and sex composition, education and health status, migration, demographic characteristics of households with the city landscape is studied .

- Folklore, one of the most important parts of the survey form. In fact, one of the principles and important aspects of cultural identity in the globalization process, according to the index, roots and Fu is Lklvr and popular culture. On this basis, a bed when cultural characteristics, including race and ethnic groups, moral and spiritual, folk literature, beliefs, folk songs, proverbs and sentence structure, language and local dialects, traditional dress and costumes, sports native, music, celebrities and personalities, official and cultural currents of scientific and literary-artistic - recreational and currents in religious and ritual and so on are discussed. In addition, according to retrospectively in the form of public debate and political history is written every city.

- In general, the linguistic identity of a city, what will be the center of attention, human cognition as the smallest member of the community. Study and understanding of human identity in the form of scenarios and action, he puts interact with the surrounding space. This section seeks to understand human identity features that have been in Shhrsakn.

\section{6-3 globalization and economic identity in Islamic cities}

One aspect of identity in urban spaces such activities by its inhabitants from the past to the present, will form the foundations of urban economy. And the city's position in the hierarchy of the spatial organization of the network of settlements and defines its relationship with other cities. What are some of the many activities that are special and are available in any particular city. And to a particular geographical location and as a pillar of identity of the city or places featured. How many network poured the economic characteristics also define the settlement. So pay attention to this dimension of urban identity is essential that the process of globalization might be attacked.

\section{6-4 globalization and the transformation of the physical-spatial identity in Islamic cities}

Cities can structure with four major dimensions for the economic, political, social and physical expression. As in Figure 1 can be seen, Economic, political reason for the existence of the city provides, and after the city was required to arrange and order and can support urban management executive arm. As well as the laws and regulations of the city. Physical, physical city, including buildings, communications networks, parks and other physical characteristics of the city to be included; And finally the social dimension of the city that it is necessary for meaning and identity and urban culture to be included. They report directly to the social problems of citizens and activities. So one of the important aspects of today's social structure of cities and urban culture is at the heart of it. Over time, the city has emerged and is now of great importance in understanding and analyzing the role of a city and its constituent patterns is paramount. It is the dominant factor identity and physical identity tissue structure and shape of the city and the main building is dependent on that identity. From the perspective of Queen Lynch elements of the image and identity of the city include:

1. roads and communication network

2. edges

3. neighborhoods

1. 4 knots

4. Symptoms

Lynch said identifying elements as the city sees mainly on physical aspects. So, texture and spatial structure of cities is one of the most important aspects of identity forms since the formation of cities, urban texture of 
thoughts, ideas, beliefs, practices and cultural level of society. The knowledge of this part of the city can learn more about other social, economic and cultural lead. The reality is that urban texture allows for visual identification provides and why it is more important than the other aspects of identity. In the process of globalization, texture in both new and old tissues have been studied. The old texture of a city manifestation of originality, historical background and living history knows many of the features by which society can recognize the historical and your actual position. However, during the development of this sector has been forgotten. For this reason, special attention was paid to this aspect. The most important aspects considered in this collection are summarized in the physical identity are:

1. The formation of the city (history of settlement and establishment of residence) and its evolution over time

2. Features and Urban Structure

3. The building blocks of texture

4. ancient places (shrines, the Temple of Fire, Holy, schools, bridges, cemeteries, buildings, monuments, etc.)

5. Access feature (road network and communication within the urban and suburban)

6. The performance characteristics of elements and components texture

7. old neighborhoods

8. axis of tourist attractions

9. The city's public open spaces

5. 10 urban views, style of architecture and urban construction etc.

All the above aspects, while providing adequate explanations associated with pictures, photos, maps and detailed sketch that allows better communication provides the reader with what has been said. In fact, reading the series as a film that globalization events and everything that can affect the show.

All the above features in a time context and different historical periods have been studied extensively and developed. In general, this collection with the introduction of identity dimensions cities try to create a reciprocal link between the past, present and future is. Thereby examines recognize that. In fact, this series seeks to rebuild the lost identity in the wake of Iran's cities is that the problems of urban identity in the globalization process from various angles, social, economic, and ecological environmental examine the and the approach of physical appropriate identify this identity has been coming to the cities.
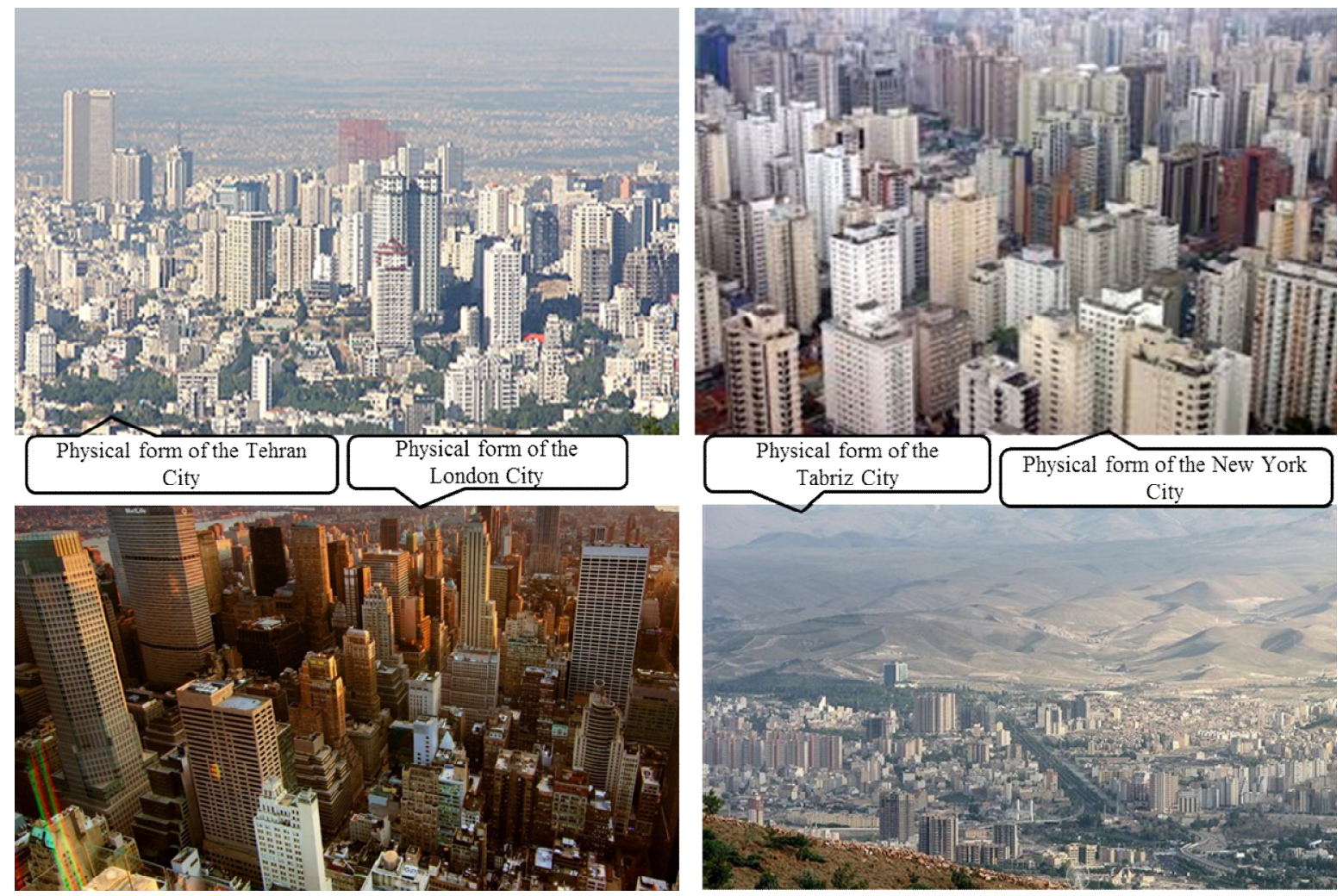

Figure 1: Integrated Form cities in the globalization process 


\section{6-5 - globalization and identity crisis of Muslim societies}

Globalization will make society change in social structures, a kind of identity crisis brought ridden and hence in many communities feeling dissipates cultural identities, ethnic, religious and national created (Sajjadi, 1381: 22). The Islamic communities in crisis and at risk of invasion of their identity and their religious and national identity in return for the release of the transformation process of globalization react the day. In addition, the West considers political Islam as well as allergens and irritating. West consciously East and the Islamic world as "other" and his dangerous rival poses and through the identification brings others to the threat of identity. In this regard, the Muslims, including Arabic countries due to the failure of Israel's history have been caught in the crisis. And by resorting more and more to its Islamic identity following the emancipation of identity crisis.

\section{Part II: Strategies for the cultural, economic, social and Iran in the Age of Globalization 1. Strategies for the cultural sector}

Prevention, strengthen the local economy in which the procedures and policies are subject to shrinkage, Because local and highlighting the new norms, beliefs and norms of qualification to prevent and thereby strengthen the normative beliefs as the foundation stone for strengthening the culture of the world. The city's cultural integrity of the collective action is the main factor after taking into account the change in organizational culture in order to prevent people and accelerating the adoption of a positive wave of globalization, it seems necessary to note the following:

- Formation of a committee to identify corporate identity.

- Determine the recognition of indigenous cultures.

- Creation of cultural unity through Gftgy cultures and civilizations.

- Taking advantage of opportunities arising from the development of networks and the media to highlight cultural features, local towns.

- Creation of stable fixed identity of the citizens of the towns historical narrative.

- Emphasis on the extent of reconstruction, reconstruction of historic towns and identity.

\section{Strategies for social sector}

With revealing the nature of social conflict perspective for social justice in cities and towns cause a participatory democracy in the cities and among citizens. the importance of the sector, civil society and nongovernmental organizations, cities and citizens to participate more fully the use of collective wisdom, also can be said that discussion and analysis of issues and needs in the perspective of citizens, according to the formulation of objectives Social programs in order to respond to their needs is maximized. So what is necessary in the social sector strategies considered are as follows?

- Recognition of the skills, capabilities and strengthen Frasrzmyny Shtrak funds in the interaction.

- Strengthening of social identity and social communication is possible and meaningful lives.

- Supporting local creative urban communities in order to create peace and prosperity.

- Development of new partnerships between governments and private companies in order to strengthen social and national creativity.

- Establish a healthy relationship between national identity and globalization.

- Choose the correct insight about the social problems of the cities.

\section{3. the economic Strategies}

Given the importance and urgency of the economic sector and plays a key role in the world, the creation of infrastructure for cities to meet the needs of multinational, and competence as a global city, providing a safe place for investment and economic activity, social and cultural rights on a global scale is essential for the metropolises of the country. because this process leaves a profound influence on the phenomenon of urbanization, The proper context of the cities in order to adapt them to meet the minimum needs of the global economy and creating a competitive environment in the community and improve the competitiveness of cities that the process is crucial, In this regard, a number of important economic policies of the Islamic Republic of Iran, with appropriate reference to the 21st century: 
- Capability, marketing, development and production and provide after sales service to the quality standards accepted by the market and the global economy.

- Creating the right environment for economic and consistency between macroeconomic policy and international politics of the country.

- Reduce tariffs and other trade restrictions to facilitate the import and export of goods and boost global trade.

- The wise policy of détente in order to obtain the identity and global identity for cities to invest.

- Encouraging neighbors south of the Persian Gulf and Central Asia to build up a global area of cities.

- Geographic focus on creating world-class financial institutions in metropolitan Tehran.

- Reducing the simple average tariff rate as other neighboring countries.

- The creation of a networked economy which components communicate with each other deeply.

- Create a competitive advantage based on the relative position within the network of cities economy.

- Replace the virtual and electronic banking in the country (virtual money to replace e-commerce).

- The importance of considering the potential economic and cities affected by national and regional circumstances.

- According to some characteristics of a place to connect with other cities in neighboring cities.

- Adopt an understanding of the interrelationships between development policy and the national economy.

- Encourage and guide the development of urban areas along the axis of the inevitable interaction with other major cities.

- Creation of the space division of labor and specialization of settlement centers and institutions active in the urban areas.

- Identify all the factors that led to the city's economy and boost their productivity.

- The digital economy and business travel markets in the world geographical space the space.

- Integration of national economies via international trade and investment.

- Clarify the economic activities of firms and markets.

\section{The strategy of the Islamic Republic in Fight Against Threats and the advantage of the opportunities of globalization:}

For the protection of cultural identity is actually an essential part of our homeland and identity is important to strengthen and enhance their cultural different levels of Gmarym efforts, Protecting and preserving the customs, and the sum of rich cultural globalization we are ready to face the new approach. What are global culture shapes people pull out every single one of their own culture; bring to the surface in the middle, and end up in a phenomenon known as global culture, its shape. Today, the amount of influence and power Brdygran (as a culture) there must be used wisely and technical means available to them earlier, naturally, a larger share of global culture designed for us in the future, they will. thus, the active role and participation of the poor and strengthen the culture and cultural elements correction and dynamic reproduction of cultural elements and time will cause proportional changes. While taking advantage of the opportunities of globalization and find a place in world culture, we also maintain their culture. and interact with other cultures to flourish and Cultural Impact of birth is required to achieve this status, intellect, wisdom and trying to stay ahead of fast convoy Alsyrthvlat and human civilization. Just and reasonable to use the phenomenon of globalization, we must ponder and enter the world in a positive direction of the noble Islamic values and human propelled, and this is what kind of experience and knowledge with careful planning by local, national and international needs, to In order to create large markets and strengthen national cultures in a culture that has always been an important element of human social life has changed reached (hazegh, nikro, 1390 , p. 11). Due to the positive and negative consequences of globalization, which cannot be indifferent to the passage of the active strategies and strategies but to enter the field?

The proposed strategies:

1. The promotion and strengthening of national, religious, and increased self-confidence in the ability of people to create a resistance against the invading alien culture.

2. The development of self-preservation, skills, and increased skills in youth and youth leaders to increase the diagnostic accuracy. 
3. The depth of the Cultural Revolution in local, regional and international level to strengthen the foundations of the domestic and international arenas to strengthen the foundations of the Islamic world and the influence of cultural theory, as well as the idea of a good fit.

4. wise management, artistic and meaningful flow of information and the use of superior technology and new media in the areas of domestic and international arena of ideas, beliefs and culture and the introduction of products and cultural products.

5. The strengthening of institutions and organizations committed to the traditions and culture of Iranian origin and faith for the deepening and development of culture and national and religious values.

6. Promote and increase the capacity of information technology, communications media, particularly affecting cross-border supply of culture, ideas and products.

7. Create the appropriate spaces of coexistence, tolerance of different cultures and ethnic groups in order to create unity and harmony.

8. Strengthening freedom, detailed, relevant and appropriate behavior model with rich Islamic culture in the social, economic and political.

9. Supply and introducing Islamic culture, history and national figures to young generations.

10. Efforts to eliminate poverty reduction and social class intervals.

11. Movement based on justice and the strengthening of justice and justice and rich behavioral model in dealing with clients and equitable distribution of national resources.

12. Strengthening the foundations of the country in order to prevent threats and perceived gaps in the global scene.

13. The planning application for the neutralization of threats, attacks and counter-cultural, disability, cultural globalization as one of the enemy.

14. Great Islamic culture and civilization in the world for global governance model to guide leaders.

15. Strengthening and developing a culture of anticipation and preparation of the internal spaces and environments, regional and global acceptance and readiness to accept and global governance.

16. Planning to take advantage of the opportunities emerging from the issue of globalization.

17. Tylygh and promotion of religious democracy and a model of democracy, scientific ideas and theories of logic and strong global levels.

18. Investment in cultural industries and information technology to the market new messages.

19. Assistance in planning for local, national and international macro level.

20.

\section{Conclusions}

Results show that the Islamic identity and the body of Islamic cities in the modern age and the globalization process has been under assault and invasion of aliens. This alienation and identity crisis for Islamic communities to follow and cause a decline in their identity, So there it necessary that Islamic scholars should think about a solution to solve this crisis and Islamic Awakening. One could also say Iranian-Islamic architecture and urbanism roots of the culture and religion of Iran is Islam and content in the body of the logic operations. And the pale imitation and role of architecture and urban planning was alien. Iranian Architectural - of Islam that is in harmony with nature and local materials in its construction have been used. Have been formed in accordance with the requirements of climate and social justice has been established that the requirements of the development of stable and sustainable urban development will be the time in which social justice is realized. But the trend in the globalization process between Iranian-Islamic architecture with modern architecture and urbanism show. The Iranian-Islamic architecture and urban planning principles and criteria governing the features and characteristics of sustainable urban development is consistent, And its stability over modern architecture and urbanism today is dominated cities.

\section{References}

[1] honor, A., check the face of globalization, Tehran, Institute for Strategic Studies, 1380.

[2] Stiglitz, Joseph, at the New World, M. Karbassian, Fountain Press, 1386.

[3] John, Tamylsvn, globalization and Traditions M. sentence translation, printing Neil, Tehran, 1381.

[4] The competent Nikravan, H., globalization and the proposed strategy with emphasis on national and religious values, 1390.

[5] Renan, M., without globalization we will never stay in Iran, Journal of Economics message, No. 14, April, 1383. 
[6] Saidi, R., Kia, AA, globalization and the role of the media in cultural identity, blessed Publications, Tehran, 1385.

[7] Vedad HTML, Imran, interactive media and communication technologies for the XXI century, translator Ali Asghar Kia, publications of the development of radio, Tehran, 1379.

[8] Friedman, Thomas, Thomas Friedman and Aegna Saver Amvnt debate about globalization, the translator Ali Divandari, jam, No. 295, the twenty-third of April, 1380.

[9] Kazemi, Ali Asghar, globalization, culture and politics (the critical analysis of theoretical, epistemological), Tehran, Ghomes Publishing, 1380.

[10]Rose, A., globalization, culture, identity, spreading straw, Third Edition, Tehran, 1386.

[11]Gybrna, Montserrat, schools nationalism, nationalism and nation - state in the twentieth century Translations Amir Masoud discretion broadcasting footage of State 1378.

[12]Pieterse, Jan Nederveen, "Globalization as Hybridization", International Sociology, vol. 9, $265-291$. (1993).

[13]Castells, Manuel, "The Rise of Network Society", Oxford, UK: Blackwell. (1996)

[14]Giddens, Anthony (1990), "The Consequences of Modernity", Stanford: Stanford University Press.

[15]Held, David, "Democracy and the Global Order: From the Modern State to Cosmopolitan Governance", Stanford: Stanford University Press, UK: Cambridge University Press. (1995).

[16]World Bank, "world development report", New York, p: 16. (1998).

[17] Schien, Edgar H. "the missing concept in organization", Cornell university, p: 229(1996). 